\title{
Degradation of Chicken Feathers by Indigenous Pseudomonas aeruginosa
}

\author{
Suharti Suharti, Laila Badriyah, and Hizkia Putraasa \\ Department of Chemistry, Faculty of Mathematics and Natural Science \\ Universitas Negeri Malang \\ J1. Semarang no 5 Malang, Indonesia \\ rusijonorusijono@gmail.com
}

\begin{abstract}
Our effort in discovering new valuable organism, A newly bacterium was isolated from chicken feathers enriched soil. Microscopic and biochemical study as well as 16S rRNA gene analysis identified the bacterium as Pseuodomonas aeruginosa. Microbial growth study confirmed its capability to use chicken feathers as a sole carbon and nitrogen source which reflects its capability to produce keratinase. Keratinase activity was measured in five consecutive days during incubation and it exhibited highest activity at second day, while chicken feather weight left is about $47 \%$ and after five days and tyrosine concentration increased during growth. Chicken feather hydrolisate contains eighteen amino acids at various concentration (two amino acids were not determined) which potential for further application such as fertilizer and animal feed. Application of keratinase crude extract in goat-skin dehairing also showed potential application in tanning industry.
\end{abstract}

Keywords-Pseudomonas; chicken feather, keratinase; amino acids, dehairing.

\section{INTRODUCTION}

Chicken feathers are abandon waste from poultry industry which consists of. $\pm 82 \%$ keratin. Keratin is fibrous protein and is constructed from amino acids, a valuable compound which can be used for many applications. However keratin is a very strong and tough macromolecule due to high concentration of disulfide bond [1]. Protease such as pepsin, try sin, papain alone cannot hydrolyze keratin because lack of disulfide reductase. Keratinase is the only enzyme known as keratin degrading enzyme.

Indonesia is a tropical country which is rich in microbial diversity. Exploration of new microbes might reveal discovery of new enzymes which can be applied for industrial purposes. One of important industrial enzyme is keratinase [2][3][4]. The activity offers many industrial applications such as milk coating [5], detergent additive [6], tanning industry [7][8], and fertilizer production [9]. This paper reports our work on isolation of new chicken feather bacterium from soil and its potential application.

\section{MATERIALS AND METHODS}

\section{A. Microbial enrichment and isolation}

Chicken feather degrading microbes in soil were enriched by mixing about $5 \mathrm{~kg}$ moistened soil with $5 \mathrm{~g}$ of chicken feather and the mixture was left under room temperature for approximately 1 month. The mixture was moisturized daily with $+10 \%(\mathrm{v} / \mathrm{w})$ of water. A soil suspension was prepared by dissolving $1 \mathrm{~g}$ soil containing decomposed chicken feathers in $100 \mathrm{~mL}$ of $0.85 \% \mathrm{NaCl}$ and a serial dilution of 1000 -fold $\left(10^{3}, 10^{6}, 10^{9}\right.$ dan $\left.10^{12}\right)$ was prepared from the suspension yielding. A $100 \mu \mathrm{L}$ of each suspension was plated on a skim-milk medium $(0.5 \%(\mathrm{w} / \mathrm{v}) \mathrm{NaCl} ; 0.1 \%(\mathrm{w} / \mathrm{v})$ $\mathrm{MgSO} 4 ; 5.0 \%(\mathrm{w} / \mathrm{v})$, and $1.5 \%(\mathrm{w} / \mathrm{v})$ bacto agar at $\mathrm{pH}$ of 7.5$)$ and incubated at $37^{\circ} \mathrm{C}$ overnight. Colonies with clear zone were picked up and tested for their ability to degrade keratin by growing it in a medium with chicken feather as sole carbon an nitrogen sources $\left(0,1 \%\right.$ chicken feathers; $0.03 \% \quad \mathrm{~K}_{2} \mathrm{HPO}_{4}$; $0.04 \% \mathrm{KH}_{2} \mathrm{PO}_{4} ; 0,05 \% \mathrm{NaCl} ; 0,01 \% \mathrm{MgCl}_{2} .6 \mathrm{H}_{2} \mathrm{O}$; and $1,5 \%$ agar). The incubation was done at $37^{\circ} \mathrm{C}$ with aeration speed of $100 \mathrm{rpm}$. Enzyme production was done using same protocol. A colony with highest turbidity at second say was selected for further analysis.

\section{B. Strain characterization}

Microbial morphological was observed microscopically, whereas in physiological observations were performed biochemical tests with MICROBACTTM GNB 12A/B/E, 24E (as a test of gram-negative bacteria). Species was determined using Bergey's Manual of Determinative Bacteriology. The result was confirmed by analysis of $16 \mathrm{~S}$ rRNA gene sequence. The gene was amplified by polymerase chain reaction (PCR) technique using internal primer $785 \mathrm{~F}^{5}{ }^{\prime}$ GGATTAGATACCCTGGTA $\left.^{3}\right)$. The amplified gene was sequenced and the resulting sequence was used as query to find homogenous 16S rRNA genes at data base using BLASTN program provided by National Centre for Biotechnology Information homepage.

\section{Keratinase activity measurement}

Activity of crude extract keratinase was determined by measuring tyrosine concentration produced per minute per millilitre crude extract. Keratin powder was used as a substrate. One $\mathrm{mL}$ of crude extract was put into a test tube. Then $1 \mathrm{~mL}$ of $1 \%(\mathrm{w} / \mathrm{v})$ keratin substrate and $\mathrm{pH} 8$ tris- $\mathrm{HCl}$ buffer were added in the test tube and the mixture was incubated for 20 minutes at $37^{\circ} \mathrm{C}$. After 20 minutes of incubation, $1 \mathrm{~mL}$ of $10 \%$ TCA solution was added to the tube to stop the enzyme activity. Complete protein precipitation was achieved by storing the reaction mixtures in the refrigerator for 15 minutes. The mixture was centrifuged at 10,000 rpm for 5 minutes. Tyrosine concentration was determined by measuring supernatant absorbance at $280 \mathrm{~nm}$.

D. Miscellaneous methods 
Amino acids content and concentration was determines using HPLC using Eurospher C18 $25 \mathrm{~cm}$, The column was equilibrated with $0.01 \mathrm{M}$ acetate buffer $\mathrm{pH} 5,9$ and the elution was done using gradient of methanol and $0.01 \mathrm{M}$ acetate buffer $\mathrm{pH}$ 5.9. Dehairing was done using $\pm 50 \mathrm{U}$ keratinase crude extract for $1 \times 1 \mathrm{~cm}^{2}$ of goat-skin at $37^{\circ} \mathrm{C}$ for $24-72 \mathrm{~h}$. The hairs were removed by scraping it using spatula. The skin surface was examined using scanning electron microscopy.

\section{RESULTS AND DISCUSSIONS}

\section{A. Strain isolation and identification}

Figure 1 showed enrichment and isolation steps. Fig 1a showed the chicken feather and moisturized soil before mixing, whereas Fig $1 \mathrm{~b}$ showed degrades chicken feather after 1 month incubation. Feather degradation indicated possible degradation by soil microorganism. Chicken feather alone without addition of soil yielded no degradation (data not shown). Chicken feather in soil might induce bacterial growth in soil. Chicken feather provided carbon and nitrogen source, however it was very difficult to degrade. In order to use chicken feather as energy and substances, microorganism in soil that capable of producing keratinase would produce the enzyme to degrade chicken feather into small molecule such as amino acids. The enzyme caused chicken feather degradation as shown in Fig $1 \mathrm{~b}$.

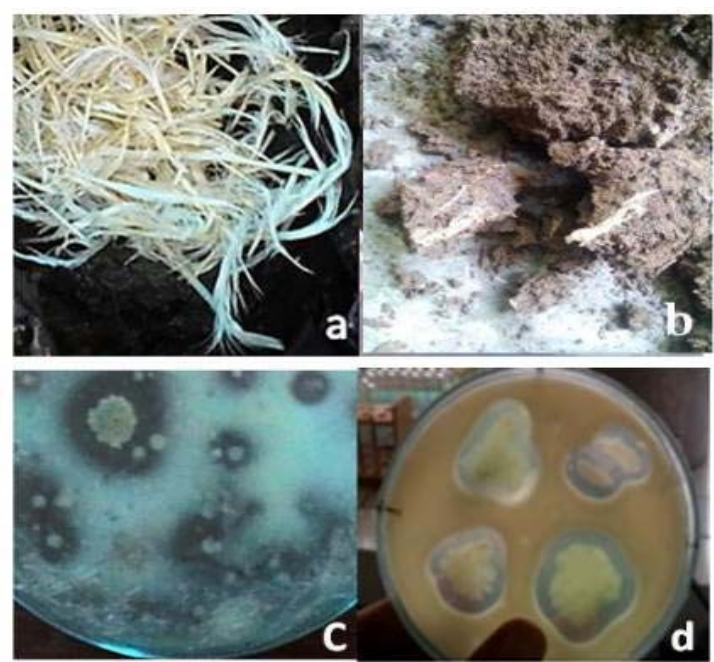

Fig 1. Bacterial soil enrichment and isolates: (a) Chicken feather and moisturized soil before incubation, (b) Chicken feather and moisturized soil after 1 month incubation, (c) Bacterial colonies on skim-milk medium, and (d) four of isolated colonies

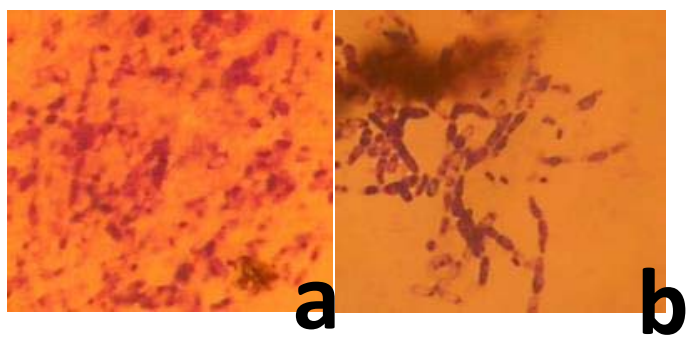

Fig 2. Gram staining of selected bacterial isolate: (a) Isolate LH and (b) Grampositive bacterium (standard)

Fig 1c showed colonies on skim-milk agar medium inoculated with soil suspension. The colonies with clear zone exhibited extracellular protease producing colonies. The loss of skim-milk emulsion indicated the presence of protease which hydrolysed emulsified skim milk into soluble hydrolisate such as amino acids and soluble polypeptides. One colony was picked and replated on fresh skim-medium (Fig 1d). Four of them was picked from 1 colony named ad LH colony. Fig 2 showed Gram staining showed that the colony is a Gramnegative bacterium (Fig 2a) compare to the purple colour of a Gram-positive bacterium standard (Fig 2b).

Table 1 showed biochemical test using MICROBACTTM GNB 12A/B/E, 24E. Cross-checked the results on Bergey's Manual of Determinative Bacteriology yielded $98.42 \%$ identity of Pseudomonas aeruginosa. The result is in a good agreement with 16S rRNA gen sequence analysis which showed $99 \%$ homology to Pseudomonas Aeruginosa strain SNP0614, Pseudomonas Aeruginosa PAO1 strain PAO1, Pseudomonas Aeruginosa strain ATCC 10145, Pseudomonas Aeruginosa strain DSM 50071, Pseudomonas Aeruginosa strain NBRC 12689, dan Pseudomonas nitroreducens strain IAM 1439. "A prokaryotic species is considered to be a group of strains that are characterized by a certain degree of phenotypic consistency, showing 70\% of DNA-DNA binding and over 97\% of $16 S$ ribosomal RNA (rRNA) gene-sequence identity" [10][11]. Therefore, it can be concluded that the newly isolated bacterium is Pseudomonas Aeruginosa. P. aeruginosa was known as a rod shape Gram-positive bacterium [12].

\section{B. Keratinase Production}

Reported keratinases for other microbial sources mostly produced by Bacillus [13], [14][15]. Pseudomonas aeruginosa KS-1 has also been reported to produce thermostable keratinase [16]. Capability of a newly isolated P. Aeruginosa degrade chicken feather was shown by its growth on a medium containing chicken feather as carbon and nitrogen source. This finding enriches microorganism collection which capable to produce keratinase. Fig 3 showed bacterium growth in chicken feather medium. After 2 days of incubation the medium became turbid and chicken feather started to degrade. Turbidity was an indication of bacterium growth which confirmed capability of $P$. Aeruginosa to degrade chicken feather. Fig 4 showed keratinase activity followed everyday for five consecutive days. The optimum enzyme activity was observed at second day. At third day the activity was dropped but slightly increased at the next days. Table 2 showed chicken weight left and tyrosine concentration during incubation time.. Chicken feathers weight decreased every day as a result of keratinase activity. Keratin in chicken feather was hydrolyzed by keratinase. The hydrolysis was confirmed by increasing tyrosine concentration.

\begin{tabular}{lllc}
\hline $\begin{array}{c}\text { Biochemical } \\
\text { test }\end{array}$ & Results & $\begin{array}{c}\text { Biochemical } \\
\text { test }\end{array}$ & Results \\
\hline Oksidase & Positive & TDA & Negative \\
Motility & Positive & Gelatin & Positive \\
Nitrate & Positive & Malonat & Negative \\
Lisyne & Positive & Inositol & Negative \\
Ornitine & Positive & Sorbitol & Negative \\
$\mathrm{H}_{2} \mathrm{~S}$ & Negative & Ramnosa & Negative \\
Glucose & Positive & Sukrosa & Negative \\
Manitol & Positive & Laktosa & Negative \\
Xilose & Positive & Arabinosa & Positive \\
ONPG & Negative & Adonitol & Negative \\
Indole & Negative & Rafinosa & Negative \\
Urease & Negative & Salisin & Negative \\
V-P & Negative & Arginin & Positive \\
Citrate & Positive & & \\
\hline
\end{tabular}

TABLE 2. Biochemical assay of selected isolate 


\section{Amino acids Production}

Increasing tyrosine concentration in chicken feather hydrolysate indicated complete hydrolysis keratin in chicken feather by keratinase. Other amino acids were analysis by HPLC and Table 2 showed amino acid content and concentration per millilitre hydrolisate. Eighteen amino acids were observed. Peak of L-and L-serine as well as L-tryptophan and L-Methionine were overlap. Cysteine and threonine were not determined. Considering low amount of chicken feather in the medium, the concentration of amino acids were enough high, which potentially can be used for further application such as animal feed and organic fertilizer. Such idea has also been proposed [17][18] [19][20].

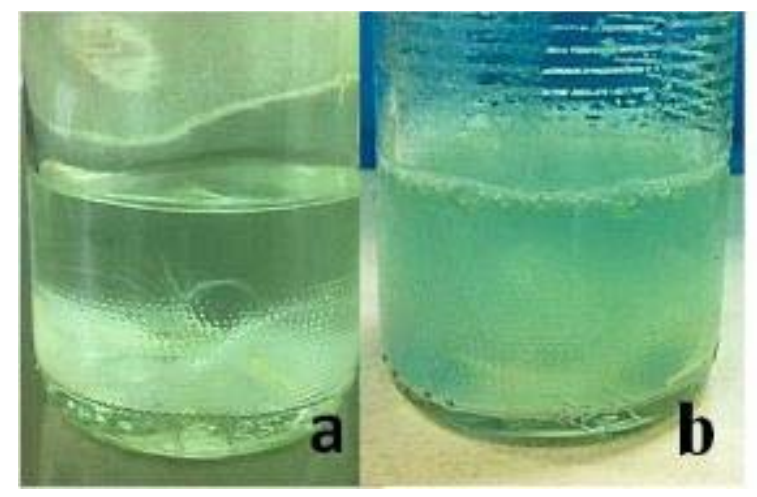

Fig 3. Bacterium growth on chicken feather medium : (a) chicken feather medium before incubation and (b) chicken feather medium after 2 days incubation

TABLE 2. Chicken feather weight left and tyrosine concentration during incubation

\begin{tabular}{ccc}
\hline $\begin{array}{c}\text { Incubation time } \\
\text { (days) }\end{array}$ & \% Weigh left & $\begin{array}{c}\text { Tyrosine } \\
\text { concentration } \\
(\boldsymbol{\mu g})\end{array}$ \\
\hline $\mathbf{1}$ & $90,92 \%$ & 12,56 \\
$\mathbf{2}$ & $73,57 \%$ & 22,83 \\
$\mathbf{3}$ & $54,84 \%$ & 23,68 \\
$\mathbf{4}$ & $48,35 \%$ & 26,40 \\
$\mathbf{5}$ & $47,01 \%$ & 32,85 \\
\hline
\end{tabular}

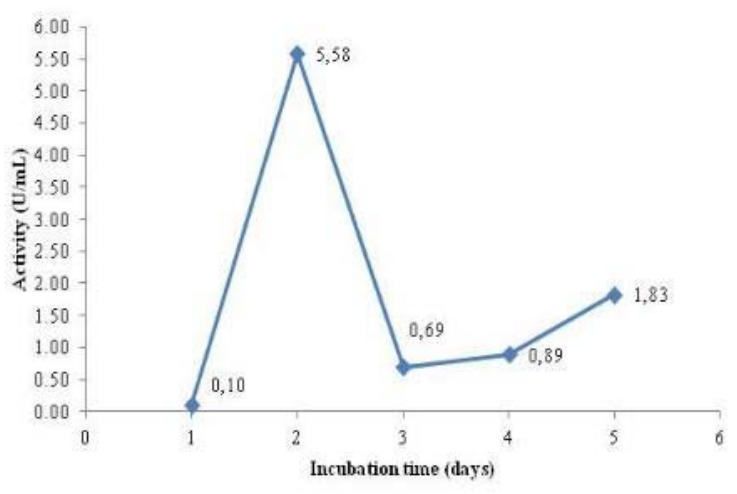

Fig 4. Keratinase activity during bacterium growth under chicken feather as sole carbon and nitrogen source

TABLE 3. Amino Acids Content and Concentration in Chicken Feather Hydrolisate

\begin{tabular}{lc}
\multicolumn{1}{c}{ Amino acids } & $\begin{array}{c}\text { Concentration } \\
\mu \mathrm{g} / \mathrm{mL}\end{array}$ \\
\hline L-aspartic acid & 59.21 \\
L-glutamic acid & 50.26 \\
L-asparagine & $<0.04$ \\
L-glutamine & $<0.05$ \\
L-threoine & 30.26 \\
L-glycine & 28.68 \\
L-arginine & 17.11 \\
L-alanine & 27.89 \\
L-tyrosine & 31.32 \\
L-tryptophane _ L-Methionine & 15.53 \\
L-valine & 16.32 \\
L-phenylalanine & 14.47 \\
L-isoleucine & 10.79 \\
L-Leucine & 21.32 \\
L-lysine & 29.21 \\
L-histidine + L-serine & 163.68 \\
\hline
\end{tabular}

\section{Potency of Crude Extract Keratinase as a Dehairing Agent}

One of environmental problem in tanning industry is the effect of chemical used. Keratinase is one of eco-friendly enzyme which has potency to be applied in tanning industry to replace the application of sodium sulfide. Fig. 5 showed application of keratinase crude extract in dehairing of goat-skin. Goat-skin hairs were successfully removed by keratinase crude extract. We recently also reported another indigenous Indonesian original bacterium which produced keratinase and the enzyme also was proven to dehair goat-skin [8].

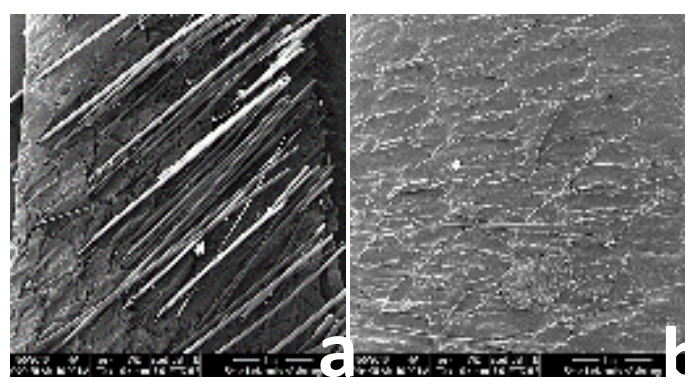

Fig 5. Photograph of goat skin at 70X Magnification; (a) skin surface profile before dehairing and (b) skin surface profiles after enzymatic dehairing using crude extract keratinase. 


\section{CONCLUSIONS}

An indigenous $P$. aeruginosa has been isolated from soil and it confirmed as keratinase producing bacterium. The highest enzyme concentration was observed at the second day and it potentially can be applied for animal skin removal at tannery industry. The bacterium degraded chicken feather, poultry industry bio-waste and cheap sustainable biomaterial. This offers great prospects to use the enzyme for degrading chicken feather into valuable materials such as creating new bio composite, animal feed, drugs, and fertilizer

\section{ACKNOWLEDGMENT}

We thanks to Ministry of Research, Technology and Higher Education of the Republic of Indonesia for financial support.

\section{REFERENCES}

[1] B. Wang, W. Yang, J. McKittrick, and M. A. Meyers, "Keratin: Structure, mechanical properties, occurrence in biological organisms, and efforts at bioinspiration," Progress in Materials Science. 2016.

[2] P. Binod, P. Palkhiwala, R. Gaikaiwari, K. Madhavan Nampoothiri, A. Duggal, K. Dey, and A. Pandey, "Industrial enzymes - Present status and future perspectives for india," J. Sci. Ind. Res. (India)., 2013, vol. 72, no. 5, pp. 271-286.

[3] A. Brandelli, "Bacterial Keratinases : Useful Enzymes for Bioprocessing Agroindustrial Wastes and Beyond,", 2008, pp. 105116.

[4] T. Paul, A. Das, A. Mandal, S. K. Halder, A. Jana, C. Maity, P. Kumar, B. R. Pati, and K. C. Mondal, "An ef fi cient cloth cleaning properties of a crude keratinase combined with detergent : towards industrial viewpoint," J. Clean. Prod., 2014, vol. 66, pp. 672-684.

[5] D. K. Sahoo, S. K. Halder, A. Das, A. Jana, T. Paul, and H. Thatoi, "Keratinase production by Bacillus weihenstephanensis PKD5 in solid-state fermentation and its milk clotting potential," vol. 14, no. April, 2015, pp. 200-207.

G. Jinsong, W. Yue, Z. Dandan, L. I. Heng, Z. Xiaomei, and Z. Rongxian, "A Surfactant-stable Bacillus pumilus K9 $\alpha$-Keratinase and Its Potential Application in Detergent Industry," 2015, vol. 31, no. 2012 .

[7] A. J. Macedo, W. O. Beys Da Silva, R. Gava, D. Driemeier, J. A. Pêgas Henriques, and C. Termignoni, "Novel keratinase from Bacillus subtilis S14 exhibiting remarkable dehairing capabilities," Appl. Environ. Microbiol., 2005, vol. 71, no. 1, pp. 594-596.

[8] S. Suharti, , Maurilla Trisna Riesmi, Arina Hidayati, Umi Faridatuz Zuhriyah and E. S. Wonorahardjo, "Enzymatic Dehairing of Goat Skin Using Keratinase from Bacillus sp. MD24, A Newly Isolated Soil Bacterium," J. Trop. Agric. Sience, 2018, vol. 41, no. 3.

[9] J. M. Kim, Y. M. Choi, and H. J. Suh, "Preparation of feather digests as fertilizer with Bacillus pumilis KHS-1," J. Microbiol. Biotechnol., 2005, vol. 15, no. 3, pp. 472-476.

[10] D. Gevers, F. M. Cohan, J. G. Lawrence, B. G. Spratt, T. Coenye, E. J. Feil, E. Stackebrandt, Y. Van de Peer, P. Vandamme, F. L. Thompson, and J. Swings, "Opinion: Re-evaluating prokaryotic species," Nat. Rev. Microbiol., 2005, vol. 3, no. 9, pp. 733-739.

[11] E. Stackebrandt and B. M. Goebel, "Taxonomic Note: A Place for DNA-DNA Reassociation and 16S rRNA Sequence Analysis in the Present Species Definition in Bacteriology," Int. J. Syst. Evol. Microbiol., 1994, vol. 44, no. 4, pp. 846-849.

[12] S. Baron, Medical Microbiology. 4th edition. 1996.

[13] R. Kumar, S. Balaji, and T. S. Uma, "Optimization of Influential Parameters for Extracellular Keratinase Production by Bacillus subtilis ( MTCC9102 ) in Solid State Fermentation Using Horn Meal - A Biowaste Management,", 2010, pp. 30-39.

[14] C. Vigneshwaran, S. Shanmugam, and T. S. Kumar, "screening and characterization of keratinase from bacillus licheniformis isolated from namakkal poultrY FARM," Researcher, 2010, vol. 2, no. 4, pp. 89-96.

[15] G. E. A. Awad, M. A. Esawy, W. A. Salam, and A. El-diwany, "Keratinase production by Bacillus pumilus GHD in solid-state fermentation using sugar cane bagasse : optimisation of culture conditions using a Box-Behnken experimental design" , 2011, pp. $663-672$.

[16] R. Sharma and R. Gupta, "Substrate specificity characterization of a thermostable keratinase from Pseudomonas aeruginosa KS-1," 2010, pp. 785-792.

[17] S. Gupta and R. Singh, "Hydrolyzing Proficiency of Keratinases in Feather Degradation," Indian J. Microbiol., 2014, vol. 54, no. 4, pp. 466-470.

[18] S. Nayaka and G. M. Vidyasagar, "Development of eco-friendly bio-fertilizer using feather compost," Ann. Plant Sci., 2013, vol. 02, no. 07 , pp. 238-244.

[19] S. Gupta, A. Nigam, and R. Singh, "Purification and characterization of a Bacillus subtilis keratinase and its prospective application in feed industry," Acta Biol. Szeged., 2015, vol. 59, no. 2, pp. 197-204.

[20] W. Suntornsuk and L. Suntornsuk, "Feather degradation by Bacillus sp. FK 46 in submerged cultivation," Bioresour. Technol., 2003 , vol. 86 , no. 3 , pp. $239-243$ 